\title{
Micellar Properties and Antimicrobial Activityof a Mixed Surfactant System Constituted by Sodium Dodecyl Sulfate and Cetylpyridinium Chloride
}

\author{
Deniz Şahin Taş* and Servet Çete \\ Faculty of Sciences, Department of Chemistry, Gazi University, Ankara 06500, TURKEY.
}

\begin{abstract}
Objective: Micellar properties of sodium dodecyl sulfate (NaDS) was examined in the presence of cetylpyridinium chloride (CPC) by means of surface tension, viscosity, dye solubilization, cloud point (CP) measurements.Antimicrobial activities of single and binary systems were also investigated. Results: A decrease in critical micelle concentration (CMC) and increase in solubilizing power for NaDS was observed with increasing CPC concentration. At the highest CPC concentration studied $(0.1 \mathrm{M})$, the surface tension decreased up to $51 \mathrm{mN} / \mathrm{m}$. Also, viscosity results showed growth in NaDS micelles (50 $\mathrm{mM}$ ) up to the $0.1 \mathrm{M} \mathrm{CPC}$ concentration. Antimicrobial activity of NaDS, CPC and NaDS in presence of CPC was investigated against ten different strains of bacteria and ayeast which was not investigated up to now. The susceptibilities of the microorganism were determined by the agar diffusion method. The results showed that NaDS and CPC have a antimicrobial activity but NaDS in presence of CPC has not antimicrobial activity on the bacterial and yeast.
\end{abstract}

Key words: Mixed Micellization, NADS, CPC, Antimicrobial Activity.

\section{INTRODUCTION}

Surfactants are widelyused in different applications such as detergents, foaming and antifoaming agents, cosmetics, floatation agentsand pharmaceuticals etc. ${ }^{1}$ The detergents and personal care products use nearly $60 \%$ of all surfactants. The biggest advantagesurfactantsis thedistinct toxic activity towards organisms due totheir surface activity. Their choice depends on many factors among which solubility of the surfactants and their CMC play an important role. ${ }^{2}$ Anionic surfactants, particularly alkylbenzene sulfonates, are the most widely used surfactants in detergents and personal care products. Cationic surfactants are not used very often in personal care products because of its very high irritation properties in comporison to other surfactants. ${ }^{3,4}$ In hygiene products as well as in the cosmetic preparations require sur- factants with low antibacterial activity and high emulsifying potentialin order to help keepskin's floraand moisture levelin balance. ${ }^{5}$ The commonly used cationic surfactants include benzylalkylammonium, alkyl quaternary ammonium, alkylpyridinium salts. Quaternary ammonium surfactants (QAS) are effective classes of antimicrobial agents and arevery widely usedin cosmetics, antiseptics, hospital sanitizers and contact lens disinfectants. ${ }^{6,7}$ Antimicrobial activity of QAS is a function of surfactant properties. ${ }^{8}$ These surfactants generally have a lowersurface tension and ahigheradsorption efficiency at the interface. ${ }^{9,10}$ In particular, QASs with alkly chains below a certain length, and so weak with surfactant properties, are ineffective as antimicrobial agents. ${ }^{11}$ These propertiesprovide their adsorption onto negatively charged bacteria surfaces. Their antibacterial properties were first
Submission Date: 16-09-2016; Revision Date: 03-01-2017; Accepted Date: 30-03-2017

DOI: 10.5530/ijper.51.4.87 Correspondence: Deniz ŞahinTaş, Faculty of Sciences, Department of Chemistry, Gazi University, Ankara 06500, TURKEY.

Tel: +903122021101

E-mail: dennoka1k@hotmail. com 
described by Jacobs and Heidelberger in 1915 studying the antibacterial activity of substituted hexamethylenetetrammonium salts. ${ }^{12,13}$ Domagk synthesized long-chain QASs, including benzalkonium chloride, and characterized their antibacterial activities, that the second important step in the work of antibacterial QASs took place. ${ }^{14}$ In general, mixtures of different types of surfactants were employed for industrial purposes. Surfactant mixtures are well known to possess better chemical and surface-active properties thanpure surfactants and thereby decreasing theirrequiredamount in applications. ${ }^{15-17}$ Most studies on mixed surfactant systems are concerned with physicochemical aspects such as CMC meaurements, micelle formation, modeling etc., of these systems. ${ }^{18-20}$ Mata et al. ${ }^{21}$ studied the micellar properties of $\mathrm{NaDS}$ inthepresence of tetrabutylammonium bromide(TBABr) and concluded that the NaDS shows a remarkable decrease in surface tension, CMC and enhanced solubilization power in presence of TBABr.

The aimof this study was to determine the stability and physicochemical and antimicrobial properties of mixedsurfactant systems.

\section{MATERIALS AND METHODS}

The anionic surfactant sodium dodecyl sulfate $(\mathrm{NaDS})$ and cationic surfactant cetylpyridinium chloride (CPC) were obtained from Fluka and were used without further purification.

Bacterial cells: Aeromonas bydrophila(106); Yerciniae entercolitice(ATCC 1501); Pseudomonos aeroginosa(ATCC 29212); Escherichia coli(ATCC 35218); Bacillus subtilis(ATCC 6633); Bacillus cereus(RSKK 863); Staphylcoccus aureus(259231); Micrococcus lutes(NRLL B-4375)

Yeast Cell: Saccaromyces cerevisiae T-32

\section{Surface tension}

The surface tension (ST) ofNaDS solutions in absence and presence of CPC was measured by drop numbers method using a stalogmometer (Traub's Stalagmometer Model 4855). Before using the stalagmometer was cleaned and dried and mounted in the vertical plane by using burette stand. In this process, first the stalagmometer was filled with distilled water as above without changing the pressure. Using the screw pinch cork, the flow rate was adjusted to $10 \mathrm{drops} / \mathrm{min}$. The number of drops of water was counted between the marks of the stalagmometer $\left(n_{1}\right)$. Water was removed and the stalagmometer was filled with $\mathrm{NaDS}$ solution containing $\mathrm{CPC}$ in concentration 0-100 $\mathrm{mM}$ and number of drops was counted $\left(n_{2}\right)$. The process was repeated three times and surface tensions were determined using formula given below.

ST of solution $\gamma_{1}=\gamma_{2}\left(n_{2} / n_{1}\right) \cdot\left(d_{1} / d_{2}\right)$

where $n_{1}=$ Number of drops of solutions

$\mathrm{d}_{1}=$ Density of solution at room temperature

$\gamma_{2}=$ Surface tension of water at room temperature $(72.8$ $\mathrm{mN} / \mathrm{m}$ )

$n_{2}=$ Number of drops of water

$\mathrm{d}_{2}=$ Density of water at room temperature $(0.99820 \mathrm{~g} /$ $\left.\mathrm{mL} ; 20^{\circ} \mathrm{C}\right)$

\section{Dye solubilization}

For the dye solubilization experiments, a water insoluble dye, orange- $\mathrm{G}\left(\mathrm{C}_{16} \mathrm{H}_{14} \mathrm{~N}_{2} \mathrm{Na}_{2} \mathrm{O}_{7} \mathrm{~S}_{2}\right)$, mol wt. $\left.=452.37\right)$ was used. The dye was shaken with an aqueous solution ofthe surfactant for 48 hours at room temperature and then the residue was removed by means of centrifugation and filtration. The absorbance of the resultant solution was then measured with an ultraviolet spectrophotometer (UV-6105) at $25^{\circ} \mathrm{C}$.

\section{Cloud point}

Cloud point was determined at fixed concentration of the $\mathrm{NaDS}(50 \mathrm{mM})$ in the absence and presence of varying amount of added CPC (0-100 mM). Surfactant solution in thin $20 \mathrm{~mL}$ glass tubes stirred with a magnetic bar while being heated. The heating rate of the sample was controlled $1^{\circ} \mathrm{C} / \mathrm{min}$. The first apperance of turbidity was taken as the cloud point.

\section{Viscosity}

The viscosity measurements were carried out using an Ubbelohde suspended level capillary viscometer. The viscometer was always suspended vertically in a thermostat at $25 \pm 0.1^{\circ} \mathrm{C}$. The viscometer was cleaned and dried every time before each measurements. The flow time forconstant volume of solution through the capillary was measured with a calibrated stopwatch.

\section{Antimicrobial activities}

Microorganisms provided from the culture collection of the Biotechnology Laboratory of the Science and Technology of Gazi University, TURKEY.

Bacterial cells and yeast cells were used as the test organisms in an antimicrobial study. Bacterial strains were inoculated into Nutrient Broth (Difco) and incubated at $30^{\circ} \mathrm{C} \pm 1.0^{\circ} \mathrm{C}$ (for $24 \mathrm{~h}$ ). In order to test antimicrobial effects of $\mathrm{NaDS}, \mathrm{CPC}$ and $\mathrm{NaDS}$ in the presence of CPC and $15 \mathrm{~mL}$ of Mueller Hinton agar (Merck) were placed in petri dishes which were then inoculated with strains of bacteria by taking $100 \mathrm{~mL}$ from cell culture media. It was left to solidify at room temperature for 
a while and then holes were made on top with a sterile stick. Test compounds prepared at the $20 \mathrm{mg} / \mathrm{mL}$ concentration. $50 \mathrm{~mL}$ of test compounds were added to the holes. Petri dishes were left at $4^{\circ} \mathrm{C}$ for $2 \mathrm{~h}$. Then bacterial cultures were incubated at $37^{\circ} \mathrm{C} \pm 1.0^{\circ} \mathrm{C}$ (for $24 \mathrm{~h}$ ).

Yeast strain was inoculated into YBD Broth (Difco) and incubated at $25^{\circ} \mathrm{C} \pm 1.0^{\circ} \mathrm{C}$ (for $48 \mathrm{~h}$ ). In order to test antimicrobial effects of $\mathrm{NaDS}, \mathrm{CPC}$ and $\mathrm{NaDS}$ in the presence of $\mathrm{CPC}$ and $15 \mathrm{~mL}$ of $Y B D$ agar were placed in petri dishes which were then inoculated with strain of bacteria by taking $100 \mathrm{~mL}$ from cell culture media. The same operations as mentioned above were as repeated. Yeast cultures incubated at $30^{\circ} \mathrm{C} \pm 1.0^{\circ} \mathrm{C}$ (for $48 \mathrm{~h}$ ). End the incubation time the inhibation zone of on the bacterial and yeast nutrient media were measured Table 1. Deionized water were used for control samples.

\section{RESULTS AND DISCUSSION}

\section{Surface-active behavior of NaDS in absence and presence of CPC}

Figure 1 shows surface-active behavior of $\mathrm{NaDS}$ in absence and presence of CPC concentrations. The surface tension of $\mathrm{NaDS}$ decreased with increasing of surfactant concentration up to CMC, beyond which no considerable change was noticed. This is a common behavior shown by surfactants in solution and is used to determine their purity and CMCs. The CMC value ofCPC in water was found to be $9.0 \times 10^{-4} \mathrm{M}$ by Schamehorn. ${ }^{15}$ The alterationof elecytrical atmosphere of $\mathrm{NaDS}$ in the presence of CPC neutralizes the effective head group charge probably resulting in reducedelecrostatic repulsion between the charged head groups andthereby tend to formmicelles at much lower concentrations. The CMC of NaDS decreased in the presence of CPC, the decrease being dependent upon the concentration of CPC. Mixtures of different surfactant types always found to have lowerCMCs and interfacial tensions than would be expected based on the properties of the pure surfactants. ${ }^{22}$ This situation leads to an increase in both theoretical and practical interest in developing a quantitative understanding of mixed surfactant behavior, and couldbe exploited in applications such as detergency, ${ }^{23}$ enhanced oil recovery 24 and mineral flotation. ${ }^{25}$ However, it is found that the correlation between the ability of a surface-active compound to lower surface tension and its ability to prevent microbial adhesion. ${ }^{26}$

\section{Solubility of dye orange-G in the surfactant micelles}

One of most importantproperties ofsurfactants is their solubilizing power. To measure solubilizing behavior of surfactants, the solubilization of water insoluble dye orange- $G$ in the surfactant micelles was studied. When the absorbance versus concentration of the $\mathrm{NaDS}$ was plotted, the linear relationships shown in Figure 2 were obtained. The absorbance for pure surfactant increases with increase in concentration of surfactant $\mathrm{NaDS}$. The results showthat the amount ofdye solubilized was insignificant up to the $\mathrm{CMC}$ of $\mathrm{NaDS}$ andthereaftera sudden steep increasewas observed with theformation of micellised surfactantin the bulk. It is evident that the solubilizing power of $\mathrm{NaDS}$ increases in the presence ofCPC. This increaseis due to thedilutedof micellar surface charge density leading to micelle swelling. The CMC so determined is in good agreement with the value obtained by surface tension technique. Variations in $\mathrm{CMC}$ values depending on the method of determination have been reported in literature. ${ }^{27}$

\section{Variation of cloud pointwith NaDS in the presence of CPC}

Figure 3 shows the variation of cloud point with $\mathrm{NaDS}$ $(50 \mathrm{mM})$ in the presence of different concentrations of $\mathrm{CPC}$. The CP decreases with increase in CPC concentration. The cloud point of a surfactant is an important factor to be considered at screening surfactant applications, because considerable changes in physical properties and, hence, in the performance of a surfactant solution is expected in temperature near the cloud point of the solution. It is well known that $\mathrm{CP}$ ischaracteristic propertyof nonionic surfactants while in case of ionic surfactants, the phenomenon is rarely observed. ${ }^{28,29} \mathrm{At}$ the cloud point, the water molecule gets very detached from micelles. For charged micelles, occurrence of the phenomenaisrarer, because presumablyelectrostatic repulsion prevents phase separation in most cases. Above its cloud point temperature or in the presence of certain additives, the aqueous nonionic surfactant solutions separate into two phases, a dilute phase and a surfactant-rich phase which is called cloud point system (CPS). The CPS is an attractive system because it provides a separation technique which is simple to operate, easy to manipulate and reliable to scale up. Especially, it provides an aqueous medium so that microbial cells will be protected from damage. ${ }^{30,31}$ Theinhibition or toxicity of both substrateand productmay be reducedand the biocompatibility may be increasedin cloud point system. Surfactants increase apparent aqueous solubility of hydrophobic organic compounds (known as solubilization) and are used to improve the bioavailability and biodegradation of these contaminants to. ${ }^{32,33}$ The experimental results show that the cloud point of $\mathrm{NaDS}$ is helpful to exploit a biocompatible medium for a microbial growth 
and then for whole cell microbial transformation in a nonaqueous medium.

Temperature and component concentration can affect the stability of the mixed micelles i.e., micelles destabilized at lower temperatures with increasing encapsulated component. For example, $0.9 \%$ of eugenol encapsulated in Surfynol ${ }^{\circledR} 485 \mathrm{~W}$ exhibited turbidity (cloud point) at $55^{\circ} \mathrm{C}$, while at $0.5 \%, 70^{\circ} \mathrm{C}$ was required to reach the cloud point. At temperatures optimal for microbial growth, micelles were stable and retained activity. ${ }^{34}$

The CP of an amphiphile can be considered as the limit of its solubility as it phase separates at temperatures above the CP. The dehydration of the surfactant's hydrophilic groups leads to the phase separationandthe formation of cloudy dispersionand it reduces repulsive interactions whichmaintainmicelles asdiscreteunits and thus facilitates micellar growth.Many theories were put forward to explain the occurrence of CP; it is still not completely resolved. ${ }^{35-37}$

The solution's cloud point is affected bythe presence of other components in a formulation. The CPs of the mixtures of the surfactants were found to be in between the $\mathrm{CP}$ of individual component surfactant. Van der waals attraction and penetration effect will help in attraction two micelles together, while the electrostatic repulsion will prevent the micellar contact. More CPC concentration will replace more structured water and phase separation is expected to appear at a lower temperature since the $\mathrm{NaDS}$ concentration is constant. This is clearly reflected from the Figure 3.

\section{Determinationof relative viscosity of $\mathrm{NaDS}$ as a function of CPC}

Figure 4 shows that relative viscosity ( $\mu$ ) of $\mathrm{NaDS}(50$ $\mathrm{mM}$ ) as a function of CPC. Relative viscosity ( $\mu$ ) of $\mathrm{NaDS}(50 \mathrm{mM})$ increased with increasing CPC concent-
ration.The formation of micelle aggregates structure from surface active molecules is governed by a delicate balance between the attractive and repulsiveinteractions of the surface free energy. In the mixtures of the surfactants viscosity show deviationfrom ideal behavior because of the electroviscous effect. If the mixed micelles form easily, the electroviscous effect will be large. As the CPC salts used in this study contain a positive charge on the $N$-atom which will decrease the effective charge of the $\mathrm{NaDS}$ and replacement of water by alkyl chains will be responsible for micellar growth.

\section{Antimicrobial Activity of Surfactants in Pure and Mixed Micelles}

Table 1 was shown that CPC and NaDS have almost been same antimicrobial activity studied concentration. Mixed ofCPC and $\mathrm{NaDS}$ have not shown antimicrobial activity against studied microorganisms except Aeremonas bydophila(106). Surfactants can inhibit the development of microorganisms in different ways. Foght et al. reported that the emulsifier, Emulsan, stimulated aromatic mineralization by pure bacterial cultures, but inhibited the degradation process when mixed cultures were used. ${ }^{38}$ Ito et al. reported thatthe sophorolipids inhibited on growth of yeast on water-insoluble substrates. ${ }^{39,40}$ According to Paul and Jeffrey (1985), dilute surfactants completely inhibited the attachment of estuarine and marine bacteria. ${ }^{41}$ They can destroy the structure of cell and inhibe some enzymes and can destroy DNA or stop the development of microorganisms by inhibition of protein synthesis. Destruction due to surfactants is the result of preferred partitioning of surfactants from the aqueous phase into cell membranes where, at low concentrations, they affect some physical properties (pressure, surface charge, etc.) which then can significantly affect a membrane protein's functions,

\begin{tabular}{|c|c|c|c|c|c|c|c|}
\hline Bacterial Strain & $\mathrm{NaDS}$ & CPC & NaDS-CPC & Bacterial Strain & NaDS & CPC & NaDS-CPC \\
\hline $\begin{array}{c}\text { Aeromonas Hydophila } \\
106\end{array}$ & 5 & 5 & 10 & $\begin{array}{l}\text { Micrococcus Luteus } \\
\text { (NRLL B-4375) }\end{array}$ & 10 & 10 & - \\
\hline $\begin{array}{c}\text { Esherichia Coli (ATCC } \\
35218)\end{array}$ & 4 & 4 & 6 & $\begin{array}{c}\text { Staphylococcus Aureus } \\
\text { (ATCC 259231) }\end{array}$ & 8 & 10 & - \\
\hline $\begin{array}{c}\text { Pseudomonas } \\
\text { aerogonisa (ATCC } \\
\text { 9212) }\end{array}$ & - & 6 & - & $\begin{array}{l}\text { Yercinia Enterecolitice } \\
\text { (ATCC 1501) }\end{array}$ & 6 & - & - \\
\hline $\begin{array}{l}\text { Bacillus cereus } \\
\text { (RSKK 863) }\end{array}$ & 9 & 8 & - & $\begin{array}{l}\text { Basillus subtilis } \\
\text { (ATCC6633) }\end{array}$ & 8 & 10 & - \\
\hline \multicolumn{8}{|l|}{ Yeast Strain } \\
\hline $\begin{array}{l}\text { Saccaromyces } \\
\text { cerevisiae T-32 }\end{array}$ & 10 & - & - & & & & \\
\hline
\end{tabular}


without a gross destruction of the membrane. At higher concentrations, closer to the surfactant CMC, an equilibrium is established between the cell membrane components associated with the lipid bilayer phase and a coexisting micellar pseudophase in the aqueous medium that results in a dissolution of several components of the lipid bilayer into micelles, destruction of cell membrane integrity, and cell lysis. ${ }^{42-44}$

In this study, surfactants my follow one ormore mechanisms which was mentioned above. Anionic surfactants themselves show marked biological activity too either binding to various bioactive macromolecules such as starch, ${ }^{45}$ proteins, ${ }^{46}$ peptides and $\mathrm{DNA}^{47}$ or by inserting into various cell fragments (i.e. phospholipid membranes) causing misfunction.

It is mentioned that $\mathrm{NaDS}$ in the presence of $\mathrm{CPC}$ is stimulate development of microorganisms and surfactant inhibition effect ofCPC is greater than SDS. Surfactants can activate or inhibite the enzyme depending

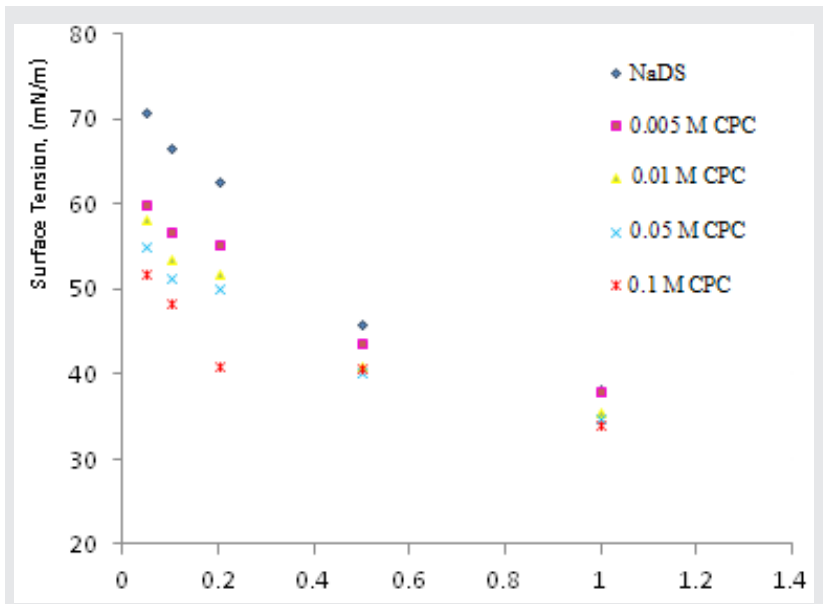

Figure 1: Surface activation behaviour of NaDS in absence and presence of CPC.

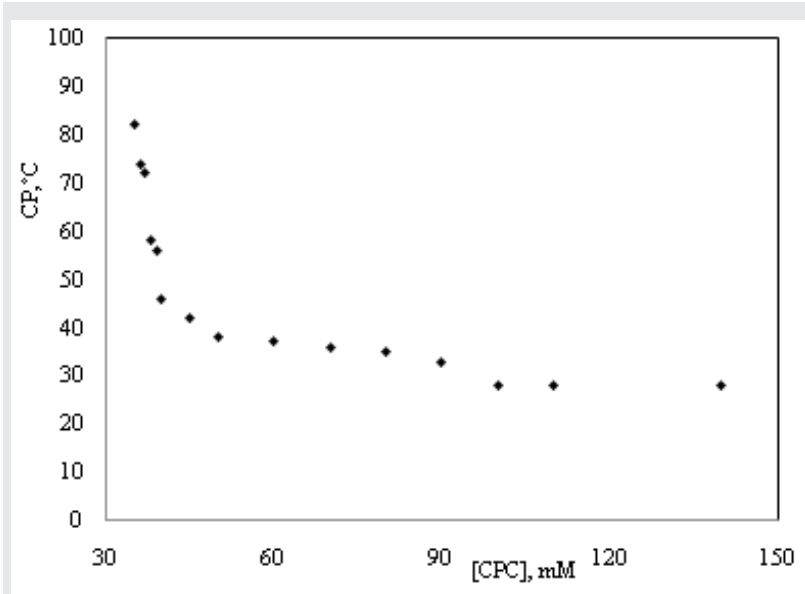

Figure 3: Cloud point of $\mathrm{NaDS}(50 \mathrm{mM})$ as a function of CPC. on the surfactant concentration and on the length of alkly chain. Cationic surfactant tested in this study was CPC greatly inhibited the enzyme activity even at the lowest concentration. All of the cationicsurfactants demonstrate goodsurface-active properties andantibacterial activity therefore they show potential applications in medical fields.Activity depends on the typeand length of substituent at the quaternary nitrogen atom. ${ }^{48,49}$ Through hydrophobic interaction by their non-polar tail, thesesurfactantscan disrupt native conformation ofthe enzyme. The non-polar tail subsequently interacts with the hydrophobic membrane core. At concentrations normally used for application to surfaces, cationic surfactants form mixed-micelle aggregates with hydrophobic membrane components that solubilize membrane and lyse the cells. Anionic surfactant, such as SDS is an anionic surfactant used in many cleaning and hygiene products and is shown by several studies to inhibit bacterial biofilm formation and disperse mature biofilms.

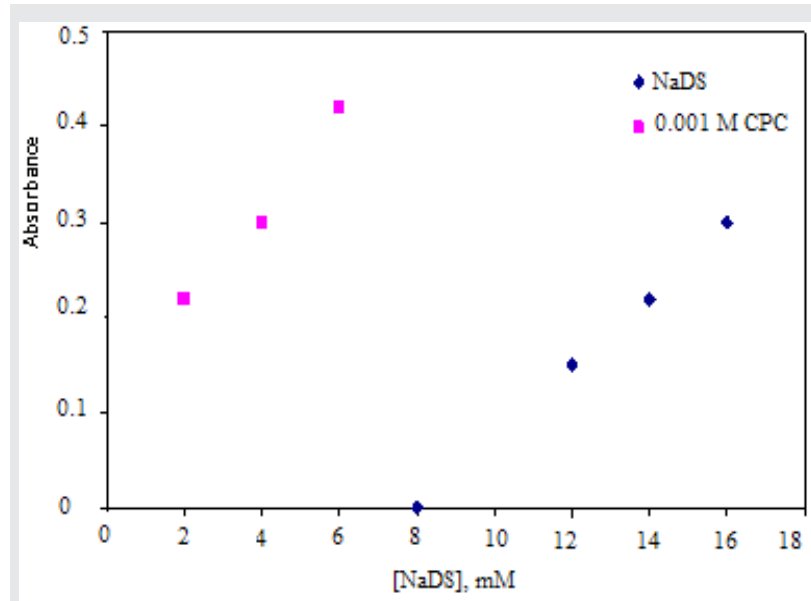

Figure 2: Absorbance of NaDS in absence and presence of CPC.

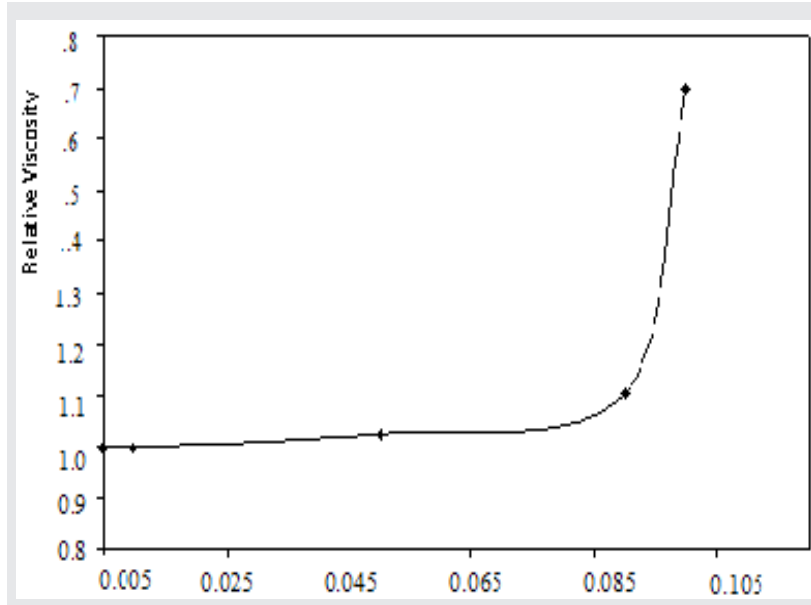

Figure 4: Relative viscosities $(\mu)$ of $\mathrm{NaDS}$ as a function of CPC. 
SDS had minimal influence on enzymatic activity when it was tested under the CMC $(0.1 \mathrm{mg} / \mathrm{mL})$. However, at $\mathrm{CMC}$ and above, SDS completely inhibited the enzyme. Moreover, as in the case of cationic surfactants, charge interactions are the primary reason for the inhibition of enzymatic activity.

$\mathrm{NaDS}$ inhibited the ATPase activity of P-glycoprotein at very low concentrations while Triton X-100 stimulated at low concentration and inhibited the activity at higher concentrations. ${ }^{50}$ Both sodium dodecyl sulfate (NaSDS) and, dodecyltrimethyl ammonium bromide (DTAB) caused inhibition of lecithin/choleseterol acyltransferease with a water-soluble substrate, whereas the nonionic surfactant Triton X-100, activated the enzyme. ${ }^{51} \mathrm{NaDS}$ and DTAB modified the structure and enzymatic activity of jack bean urease ${ }^{52}$ and $\mathrm{NaDS}$ activated latent potato leaf polyphenol oxidase. ${ }^{53}$ It was found that the interaction between the peptide and $\mathrm{NaDS}$ is of exclusively electrostatic character with the six positively charged arginines of the peptide acting as binding sites for $\mathrm{NaDS}$. This binding may explain that similar to other as binding sites for $\mathrm{NaDS}^{54}$ surfactants show in vitro antiviral activiy against HIV-1, HIV-2 and other enveloped viruses. ${ }^{55}$ Anionic surfactants influence enzyme activities has been extensively demonstrated. Thus, it was proved that linear alkly benzene sulfonate can accumulate in the hepatic liposomes of the rate and can inhibit the activity of the enzymes alkaline phosphatese and acid phosphatase. ${ }^{56}$

\section{CONCLUSION}

Micellar and antimicrobial behavior ofNaDS and CPC mixtures in aqueous media has been investigated with help of surface tensiometry, dye solubilization, viscosity, CP, antimicrobial activities. NaDS shows a remerkable decrease in surface tension, CMC and enhanced solubilization power in the presence of CPC. Clouding phenomena was observed at room temperature in NaDS-CPC systems. Studied bacterias are recognized as human pathogens. We can say that both $\mathrm{NaDS}$ and CPC can use in the application against studied microorganics.

\section{ACKNOWLEDGEMENT}

Thanks to the Biotechnology Laboratory of the Science and Technology of Gazi University for providing the microorganisms.

\section{CONFLICT OF INTEREST}

There is no conflict of interest.

\section{ABBREVIATIONS USED}

CMC: Critical micelle concentration; CPC: Cetylpyridinium chloride; CP: Cloud point; CPS: Cloud point system; $\mathbf{d}_{1}$ : Density of solution at room temperature; $\mathbf{d}_{2}$ : Density of water at room temperature $(0.99820 \mathrm{~g} / \mathrm{mL}$; $\left.20^{\circ} \mathrm{C}\right) ; \boldsymbol{n}_{1}$ : Number of drops of solutions; $\boldsymbol{n}_{2}$ : Number of drops of water; $\gamma_{2}:$ Surface tension of water at room temperature $(72.8 \mathrm{mN} / \mathrm{m}) ; \boldsymbol{\mu}$ : Relative viscosity; NaDS: Sodium dodecyl sulfate; QAS: Quaternary ammonium surfactants; TBABr: Tetrabutylammonium bromide.

\section{REFERENCES}

1. Holland PM, Rubingh D. Mixed Surfactant Systems: ACS Symposium Series 501, American Chemical Society, Washington DC, (chapter1) 1992;31-44.

2. Tai LHT, Nardello-Rataj V. Detergents The main surfactants used in detergents and personal care products. Lipides. 2001;8(2):141-4.http:// dx.doi.org/10.1051/ocl.2001.0141.

3. Merianos JJ. in S.S. Block (Ed.), Disinfection, sterilazition, and preservation, fourth ed., Lea and Febiger, Philadelphia, 1996;225-55.

4. Steichen D. Cationic Surfactants in Handbook of Applied Surface and Colloid Chemistry, Holmber, K., Ed., John Wiley\&Sns: Chicestr, 2002; (chapter14) 309-49.

5. Hill K. Sugar-Based Surfactants for Consumer Products and Technical Applications. Fett-Lipid 1. 1999;25-33.https://doi.org/10.1002/(SICl)15214133(19991)101:1<25::AID-LIPI25>3.0.CO;2-N.

6. Ascenzi JM. Handbook of Disinfections and Antiseptics, Marcel Dekker Inc, New York, 1996;871-86.

7. Ioannou CJ, Hanlon GW, Denyer SP. Action of Disinfectant Quaternary Ammonium Compounds against Staphylococcus aureus. Antimicrob. Agents Chemother. 2007;51(1):296-306. DOI:10.1128/AAC.00375-06.https://doi. org/10.1128/AAC.00375-06.

8. Tischer M. Pradel G, Ohlsen K, Holzgrabe U. Quaternary ammonium salts and their antimicrobial potential: targets or nonspecific interactions?. Chem Med Chem. 2012;7(1):22-31. DOI: 10.1002/cmdc.201100404.https://doi. org/10.1002/cmdc. 201100404 .

9. Davis J. Bacteria on the rampage. Nature. 1996;383:219-20. DOI:10.1038/383219a0.https://doi.org/10.1038/383219a0.

10. Jones MV, Herd TM, Christie HJ. Resistance of Pseudomonas Aeruginosa to amphoteric and quaternary ammonium biocides. Microbies. 1998;58(234):4961.

11. Denyer SP, Stewart GSAB. Mechanisms of action of disinfectants. Int Biodeter Biodegred. 1998;41:261-8.https://doi.org/10.1016/S0964-8305(98)00023-7.

12. Jacobs WA, Heidelberger $M$. The quaternary salts of hexamethylenetetramine. I. substituted benzyl halides and the hexamethylenetetraminium salts derived therefrom. J Biol Chem. 1915;20(4):659-83.

13. Jacobs WA. The bactericidal properties of the quaternary salts of hexamethylenetetramine I. The problem of the chemotherapy of experimental bacterial infections. J Exp Med. 1916;23:563-8.https://doi.org/10.1084/ jem.23.5.563 ; PMid:19868007 PMCid:PMC2125441.

14. Domagk GA. New class of disinfectants. Dtsch Med Wochenschr. 1935;61:829-32.https://doi.org/10.1055/s-0028-1129654.

15. Schamehorn JF. In Phenomena in Mixed Surfactant Systems: ACS Symposium Series 311, American Chemical Society, Washington DC, 1986;324-37. DOI: 10.1021/bk-1986-0311.ch024.https://doi.org/10.1021/bk1986-0311.ch024.

16. Bhat M, Gaikar VG. Characterization of interaction between butyl benzene sulfonates and cetyl trimethylammonium bromide in mixed aggregate systems. Langmuir. 1999;15(14):4740-51.https://doi.org/10.1021/la981439w.

17. Gandhi H, Varade D, Bahadur P. Mixed micelles of anionic and cationic surfactants in aqueous solutions. Tenside Sur Det. 2002;39(3):16-9.

18. Zana R, Muto Y, Esumi K, Meguro K. Mixed micelle formation between alkymethyl ammonium bromide and alkane- $\omega$-bis(trimethylammonium) 
bromide, in aqueous solution. Journal of Colloid and Interface Science. 1988;123:502-11.https://doi.org/10.1016/0021-9797(88)90272-X.

19. Velázquez MM, García-Mateos I, Lorente F, Valero M, Rodríguez LJ. Fluorescence studies on the characterization of mixed micelles. Journal of Molecular Liquids. 1990;45:95-100.https://doi.org/10.1016/01677322(90)80018-F.

20. Garamus VM. Study of mixed micelles with varying temperature by smallangle neutron scattering. Langmuir. 1997;13(24):6388-92. DOI: 10.1021/ la970011e.https://doi.org/10.1021/la970011e.

21. Mata J, Varade D, Ghosh G, Bahadur P. Effect of tetrabutylammonium bromide on the micelles of sodium dodecyl sulfate. Colloid and Sur A. 2004;245(1):69-73.https://doi.org/10.1016/j.colsurfa.2004.07.009.

22. Rosen MJ. Surfactants and interfacial phenomena. Wiley New York. 2004;208-43.https://doi.org/10.1002/0471670561.

23. Jost F, Leiter H, Schwuger MJ. Synergisms in binary surfactant mixtures. Colloid Polym Sci. 1988;266:554-61.https://doi.org/10.1007/BF01420767.

24. Shah DO, Schechter RS. Improved Oil Recovery by Surfactant and Polymer Flooding; Eds.; Academic Press: New York, NY, 1977.

25. Dobias B. In Phenomena in Mixed Surfactant Systems; Scamehorn, J. F, Ed.; ACS Symposium Series 311, American Chemical Society: Washington, DC,1986; 216-24. DOI: 10.1021/bk-1986-0311.ch016.https://doi. org/10.1021/bk-1986-0311.ch016.

26. Whitekettle WK. Effects of surface-active chemicals on microbial adhesion. Journal of Industrial Microbiology. 1991;7:105-16.https://doi.org/10.1007/ BF01576072.

27. Patel J. Effect of tetrabutylammonium bromide on the micellar behaviour of ionic surfactant. Indian J of Chem. 2004;43:715-21.

28. Schick MJ. Nonionic Surfactants: Physical Chemistry, second ed., Marcel Dekker, New York, 1987.

29. Warr GG, Zemb TN, Drifford M. Liquid-liquid phase separation in cationic micellar solutions. J. Phys. Chem. 1990;94:3086-92.https://doi.org/10.1021/ j100370a063.

30. Wang Z, Zhao F, Hao X, Chen D, Li D. Microbial transformation hydrophobic compound in cloud point system. J Mol Catal B: Enzymatic. 2004;27(4):14753.https://doi.org/10.1016/j.molcatb.2003.11.002.

31. Wang Z, Xu J-H, Wang L, Bao D, Qi H. Thermodynamic equilibrium control of the enzymatic hydrolysis of penicillin $\mathrm{G}$ in a cloud point system without $\mathrm{pH}$ control. Ind Eng Chem Res. 2006;45(24):8049-55. DOI: 10.1021/ie060418r. https://doi.org/10.1021/ie060418r.

32. Billingsley KA, Backus SM, Ward OP. Effect of surfactant solubilization on biodegradation of polychlorinated biphenyl congeners by Pseudomonas LB400. Appl Microbiol Biotechnol. 1999;52(2):255-60.https://doi.org/10.1007/ s002530051518; PMid:10499265.

33. Churchill PF, Dudley RJ, Churchill SA. Surfactant-enhanced bioremediation. Waste Manag. 1995;15:371-77.https://doi.org/10.1016/0956053X(95)00038-2.

34. Segura SG. Physicochemical and antimicrobial properties of antimicrobials

35. Yu ZJ, Xu G. Physicochemical properties of aqueous mixtures of tetrabutylammonium bromides and anionic surfactants 1. Temperatureinduced micellar growth and cloud point phenomenon. J Phys Chem. 1989;93(21):7441-45.https://doi.org/10.1021/j100358a037.

36. Raghavan SR, Edlund H, Kaler EW. Cloud-point phenomena in wormlike micellar systems containing cationic surfactant and salt. Langmuir. 2002;18(4):1056-64.https://doi.org/10.1021/la011148e.

37. Bales $B L$, Zana R. Cloud point of aqueous solutions of tetrabutylammonium dodecyl sulfate is a function of the concentration of counterions in the aqueous phase. Langmuir. 2004;20(5):1579-81.https://doi.org/10.1021/ la0353935.

38. Foght JM, Gutnick DL, Westlake DWS. Effect of emulsan on biodegradation of crude oil by pure and mixed bacterial cultures. Appl Environ Microbiol. 1989;55(1):36-42.PMid:16347832 PMCid:PMC184051.
39. Ito S, Inoue S. Sophorolipids from Torulopsis bombicola: possible relation to alkane uptake. Appl. Environ. Microbiol. 1982;47:1278-83.

40. Ito S, Kinta M, Inoue S. Growth of yeasts on N-alkanes: inhibition by a lactonic sophorolipid produced by Torulopsis bombicola. Agric Biol Chem. 1980;44(9):2221-4. DOI: 10.1080/00021369.1980.10864301.https://doi.org/ 10.1080/00021369.1980.10864301.

41. Paul JH, Jeffrey $\mathrm{WH}$. The effect of surfactants on the attachment of estuarine and marine bacteria to surfaces. Can J Microbiol. 1985;31(3):224-28.https:// doi.org/10.1139/m85-043.

42. Lichtenberg D, Opatowski E, Kozlov MM. Phase boundaries in mixtures of membrane-forming amphiphiles and micelle-forming amphiphiles. Biochim Biophys Acta. 2000;1508:1-19.https://doi.org/10.1016/S03044157(00)00004-6.

43. Prete PS, Domingues CC, Meirelles NC, Malheiros SV, Go-i FM, de Paula E, Schreier S. Multiple stages of detergent-erythrocyte membrane interaction: a spin label study. Biochim Biophys Acta. 2011;1808(1):164-70. DOI:10.1016/j. bbamem.2010.10.016.https://doi.org/10.1016/j.bbamem.2010.10.016.

44. Inácio SI. et al. Mitochondrial dysfunction is the focus of quaternary ammonium surfactant toxicity to mammalian epithelial cells. Antimicrob Agents Chemother. 2013;57(6):2631-39. DOI:10.1128/AAC.02437-12. https://doi.org/10.1128/AAC.02437-12.

45. Merta J, Stenius P. Interactions between cationic starch and mixed anionic surfactants. Colloid and Sur A. 1999;149(1):367-77.https://doi.org/10.1016/ S0927-7757(98)00418-X.

46. Nielson AD. et al. Thermochemistry of the specific binding of $\mathrm{C} 12$ surfactants to bovine serum albumin. Biocim Biophys Acta. 2000;1479(1):321-31.https:// doi.org/10.1016/S0167-4838(00)00012-1.

47. Marques E. et al. Gel formation and association in systems of cationic surfactant vescicles and oppositely charged polymers. American Chemical Society Polym Prepr. 2000;41:737-38.

48. Zhang S, Ding S, Yu J, Chen X, Lei Q, Fang W. Antibacterial activity, in vitro cytotoxicity, and cell cycle arrest of gemini quaternary ammonium surfactants. Langmuir. 2015;31(44):12161-9. DOI:10.1021/acs.langmuir.5b01430.https:// doi.org/10.1021/acs.langmuir.5b01430.

49. Pernak J, Mırska I, Kmiecik R. Antimicrobial activities of new analogues of benzalkonium chloride. Eur J Med Chem. 1999;34(9):765-71. http:// dx.doi.org/10.1016/S0223-5234(99)00216-0https://doi.org/10.1016/S02235234(99)00216-0.

50. Doige CA, Yu X, Sharom FJ. The effects of lipids and detergents on ATPaseactive P-glycoprotein. Biocim. Biophys Acta. 1993;1146(1):65-72.https://doi. org/10.1016/0005-2736(93)90339-2.

51. Boneli FS, Jonas A. Reaction of lecithin: cholesterol acyltransferase with a water soluble substrate: effects of surfactants. Biocim Biophys Acta. 1993;1166(1):92-8.https://doi.org/10.1016/0005-2760(93)90288-K.

52. Hirai M. et al. Structural change of jack bean urease induced by addition surfactants studied with synchrotron-radiation small-angle X-ray scattering. Eur J Biochem. 1993;215(1):55-61.https://doi.org/10.1111/j.1432-1033.1993. tb18006.x ; PMid:8344285.

53. Sanchez-Ferer A, Laveda F, Garcia-Carmona F. Substrate-dependent activation of latent potato leaf polyphenol oxidase by anionic surfactants. J Agric Food Chem. 1993;41(10):1583-86. DOI: 10.1021/jf00034a010.https:// doi.org/10.1021/jf00034a010.

54. Gawrisch K. et al. Interaction of peptide fragment 828-848 of the envelope glycoprotein of human immunodeficiency virus type I with lipid bilayers. Biochem. 1993;30:3112-18.https://doi.org/10.1021/bi00063a024.

55. Lüscher-Mattli M. Polyanions-a lost chance in the fight against HIV and other virus diseases?. Antivir Chem Chemother. 2000;11(4):249-59.https://doi. org/10.1177/095632020001100401; PMid:10950387.

56. Bragadin M, Perin G, Raccanelli S, Manentc S. The accumulation in lysosomes of the anionic detergent linear alkylbenzene sulfonate. Environ Toxicol Chem. 1996;15(10):1749-52. DOI: 10.1002/etc.5620151014.https:// doi.org/10.1002/etc.5620151014. 


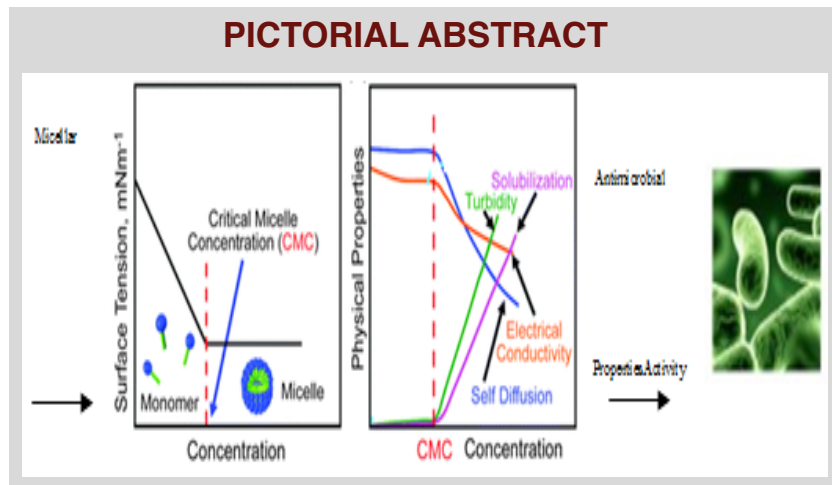

- A decrease in critical micelle concentration (CMC) and increase in solubilizing power for $\mathrm{NaDS}$ was observed with increasing CPC concentration.

- Both NaDS and CPC can use in the application against studied microorganics.

\section{About Authors}

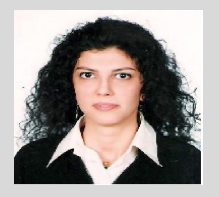

Deniz Șahin Taș: Working as postdoctorate student School of Chemical Engineering, Universitat Rovira I Virgili, Spain.

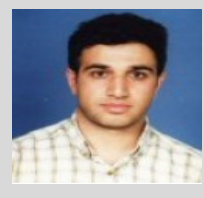

Servet Çete: Working as Assosicate Professor ,Faculty of Sciences, Department of Chemistry, Gazi University, Ankara, TURKEY.

Cite this article: Taş DS, Çete S. Micellar Properties and AntimicrobialActivityof a Mixed Surfactant System Constituted by Sodium Dodecyl Sulfate and Cetylpyridinium Chloride. Indian Journal of Pharmaceutical Education and Research. 2017;51(4):580-7. 